\title{
RADIOPROTECTIVE EFFECTS OF ALOE VERA ON HEPATOSOMATIC INDEX OF SWISS ALBINO MICE
}

\author{
PRIYANKA DADUPANTHI
}

Biyani Girls College, Jaipur, India

Email: drpriyankadadupanthi81@gmail.com

Received: 15 Apr 2019, Revised and Accepted: 13 Jun 2019

\begin{abstract}
Objective: In the living organisms, deleterious effects produced by ionizing radiations. Human exposure to ionizing radiations increased enormously because of rapid technological advancements. There is a need to protect humans against such effects of ionizing radiation. Protection against the deleterious effects of ionizing radiations by radioprotectors was studied, which may be of great help for human application. Present study was conducted to evaluate the modulating efficacy of prolonged administration of Aloe vera extract against gamma irradiation-induced toxicity in mice.
\end{abstract}

Methods: Animals were given Aloe vera leaf extract orally $1000 \mathrm{mg} / \mathrm{kg}$ body weight/d for 15 consecutive days before radiation exposure (0.5, 3 and 5.5 Gy gamma radiation).

Results: Mice were autopsied at day 1/4, 1, 3, 5, 10 and 20 after irradiation to evaluate the radio modulator effect in terms of the hepatosomatic index.

Conclusion: Aloe vera extract has a beneficial protective effect against radiation-induced oxidative stress.

Keywords: Radiation, Hepatosomatic index, Aloe vera, Radioprotector

(C) 2019 The Authors. Published by Innovare Academic Sciences Pvt Ltd. This is an open access article under the CC BY license (http://creativecommons.org/licenses/by/4.0/) DOI: http://dx.doi.org/10.22159/ijcpr.2019v11i4.34935

\section{INTRODUCTION}

We all are familiar with the harmful effects of radiations. Due to rapid technological advancement, day by day the level of radiation is increasing; therefore there is a need to protect living beings against such harmful effects. Radiation is the energy released in the form of electromagnetic waves or particle. As a response to ionizing radiation, Reactive oxygen species (ROS) such as hydroxyl radical $(\mathrm{OH})$, superoxide anion radicals and hydrogen peroxide $\left(\mathrm{H}_{2} \mathrm{O}_{2}\right)$ are produced [1]. As a consequence, it is essential to search radio protectors to control side effects in both planned exposure such as radiotherapy and unplanned exposure such as natural radiation [2]. Although synthetic compounds including thiols, baminothiols, thiadiazoles, or benzothiazoles reveal certain radioprotective effects, their side effects have also gained extensive attention [3]. Therefore, it is a promising strategy to develop natural radioprotectors from plants and herbs [4]. Many plant extracts have been reported to contain antioxidants that scavenge free radicals produced due to radiation exposure. It has antioxidants properties because it contains vitamin A (carotene), C, B and vitamin E [5]. The liver is an active metabolic organ and it can be easily influenced by many environmental conditions. Ionizing radiation is one of such environmental factor. Therefore the present study was conducted to evaluate the protective effects of Aloe vera against radiation-induced hepatic damage.

\section{MATERIALS AND METHODS}

\section{Animals}

Male Swiss albino mice 6-8 $\mathrm{w}$ old $26 \pm 2 \mathrm{~g}$ were used, they were given standard mice feed and water. The maintenance and handling of the animals were done according to the guidelines of the Committee for the Purpose of Control and Supervision of experimental animals, Ministry of Environment and Forests, Government of India. All the experimental work was approved by the institutional animal ethics committee.

\section{Source of radiation}

Animals were treated with cobalt-60 source of radiation in radiotherapy Dept. SMS hospital, Jaipur. On exposure to radiation, animals were kept in a ventilated box and the radiation dose given to these animals were $0.5,3$ and $5.5 \mathrm{~Gy}$.

\section{Experimental design}

Animals were divided into three groups.

Group I: Animals were administrated with double distilled water only (i.e. normal).

Group II: Animals was orally given Aloe vera drug (i.e. drug alone).

Group III: This was further divided into 2 sets i.e. control and experimental. Animals of the control set were treated with radiation and animal of the experimental set were treated with both drugs and radiation. The radiation doses given to animals were $0.5,3$ and 5.5 Gy and the animals were autopsied at the interval of $6 \mathrm{~h}$, day $1,3,5,10$ and 20 .

Hepatosomatic index

Hepatosomatic index is a percent ratio of liver weight to animal weight.

$$
\underset{(\text { gm/100 gm body wt. })}{\text { Hepatosomatic index }}=\frac{\text { Weight of liver }}{\text { Weight of animal }} \times 100
$$

\section{RESULTS}

Value of hepatosomatic index in normal mice (group I) was considered as 100 percent, which decreased to 96.35 percent in mice treated with Aloe alone (group II) as represented in table 1 and fig. 1.

In animals of Control set III (0.5 Gy) hepatosomatic index increased gradually from $6 \mathrm{~h}$ in 0.5 Gy irradiated animals and reached at the highest level $(116.49 \%)$ on day 3 post-irradiation. Thereafter, it tended to decrease and returned almost to normal level (101.84\%) at day 20 respectively whereas in Aloe treated 0.5 Gy irradiated animals hepatosomatic index also increased from $6 \mathrm{~h}$ to day 3 but the increase was significantly lesser $(p<0.05)$ than that of 0.5 irradiated alone animals. After it, the value of the hepatosomatic index decreased and reached a normal level at day 20. 
After irradiation with $3 \mathrm{~Gy}$, the value of the hepatosomatic index was found 106.53 percent at the first autopsy interval $(6 \mathrm{~h})$.

The increasing pattern persisted and a peak (117.06 \%) was seen at day 3. Later, a declining trend was noticed but did not return to the normal level and remained higher (nonsignificant) up to last autopsy interval (day 20). Value of hepatosomatic index in experimental set (Aloe treatment+3 Gy) was increased from $6 \mathrm{~h}$ to day 3 and measured as 101.65, 105.59 and 114.43 percent at $6 \mathrm{~h}$, day 1 and 3 post-irradiation respectively. But each value was found to be significantly lower than its respective control set. Thereafter, it declined progressively from day 5 to last autopsy interval and found 106.32 percent at day 20 .
Hepatosomatic index was 107.85 percent at $6 \mathrm{~h}$ postirradiation in 5.5 Gy exposed animals, which further increased and reached at a peak level (120.81\%) on day 3. Later, a continuous decrease was seen in the hepatosomatic index up to last autopsy interval (day 20) but did not return to the normal level and still found 112.92 percent. In Aloe treated 5.5 Gy irradiated animals value of the hepatosomatic index was found 104.84 percent at $6 \mathrm{~h}$ postirradiation but this increase was significantly lesser $(p<0.05)$ than that of 5.5 irradiated alone animals. The increasing pattern persisted and a peak was measured (133.39\%) at day 3 . Thereafter, the hepatosomatic index decreased progressively up to last autopsy interval (day 20) and found 108.23 percent at day 20 post-irradiation (table 1, fig. 1).

Table 1: Hepatosomatic index (gm/100 gm body wt.) in Swiss albino mice exposed to different doses of gamma radiation with and without pretreatment of Aloe

\begin{tabular}{|c|c|c|c|c|c|c|}
\hline \multirow{2}{*}{$\begin{array}{l}\text { Autopsy intervals } \\
\text { (days) }\end{array}$} & \multicolumn{2}{|l|}{ Group III } & \multicolumn{2}{|l|}{ Group IV } & \multicolumn{2}{|l|}{ Group V } \\
\hline & $\begin{array}{l}\text { Cont. set III } \\
(\mathrm{DDW}+0.5 \mathrm{~Gy})\end{array}$ & $\begin{array}{l}\text { Exptl. set III } \\
(\text { Aloe+0.5 Gy })\end{array}$ & $\begin{array}{l}\text { Cont. set IV } \\
\text { (DDW+3 Gy) }\end{array}$ & $\begin{array}{l}\text { Exptl. set IV } \\
(\text { Aloe+0.5 Gy) }\end{array}$ & $\begin{array}{l}\text { Cont. set V } \\
(D D W+5.5 \text { Gy) }\end{array}$ & $\begin{array}{l}\text { Exptl. set V } \\
(\text { Aloe+5.5 Gy) }\end{array}$ \\
\hline \multirow[t]{2}{*}{$1 / 4$ (6 h.) } & $5.47 \pm 0.14^{\mathrm{NS}}$ & $5.39 \pm 0.08^{\mathrm{NS}}$ & $5.67 \pm 0.32 *$ & $5.41 \pm 0.28^{\mathrm{NS}}$ & $5.74 \pm 0.28^{*}$ & $5.58 \pm 0.25^{*}$ \\
\hline & $(102.78)$ & (101.27) & $(106.53)$ & (101.65) & (107.85) & (104.84) \\
\hline \multirow[t]{2}{*}{1} & $5.59 \pm 0.06^{*}$ & $5.57 \pm 0.24^{\mathrm{NS}}$ & $5.78 \pm 0.21^{*}$ & $5.62 \pm 0.20 *$ & $5.89 \pm 0.25^{*}$ & $5.83 \pm 0.22 *$ \\
\hline & (105.03) & $(104.66)$ & $(108.60)$ & (105.59) & (110.67) & $(109.54)$ \\
\hline \multirow[t]{2}{*}{3} & $6.20 \pm 0.03 *$ & $6.06 \pm 0.22 *$ & $6.23 \pm 0.26^{*}$ & $6.09 \pm 0.18^{*}$ & $6.43 \pm 0.19 *$ & $6.26 \pm 0.16^{*}$ \\
\hline & (116.49) & $(113.43)$ & $(117.06)$ & $(114.43)$ & (120.81) & $(117.62)$ \\
\hline \multirow[t]{2}{*}{5} & $5.92 \pm 0.16^{*}$ & $5.84 \pm 0.18^{*}$ & $6.16 \pm 0.20^{*}$ & $5.95 \pm 0.19^{*}$ & $6.22 \pm 0.21^{*}$ & $5.98 \pm 0.18^{*}$ \\
\hline & (112.23) & (109.73) & (115.74) & (111.80) & (116.87) & $(112.36)$ \\
\hline \multirow[t]{2}{*}{10} & $5.58 \pm 0.21 *$ & $5.49 \pm 0.20 *$ & $6.03 \pm 0.16^{*}$ & $5.85 \pm 0.21 *$ & $6.17 \pm 0.16^{*}$ & $5.88 \pm 0.19 *$ \\
\hline & $(104.84)$ & (103.15) & (113.30) & (109.92) & (115.93) & $(110.48)$ \\
\hline \multirow[t]{2}{*}{20} & $5.42 \pm 0.18^{\mathrm{NS}}$ & $5.33 \pm 0.16^{\mathrm{NS}}$ & $5.86 \pm 0.18^{*}$ & $5.66 \pm 0.16^{*}$ & $6.01 \pm 0.22^{\mathrm{NS}}$ & $5.76 \pm 0.20 *$ \\
\hline & $(101.84)$ & $(100.01)$ & $(110.10)$ & $(106.35)$ & $(112.92)$ & $(108.23)$ \\
\hline
\end{tabular}

Significance level ${ }^{*}{ }^{*} \mathrm{p}<0.05 \mathrm{NS}=$ Nonsignificant

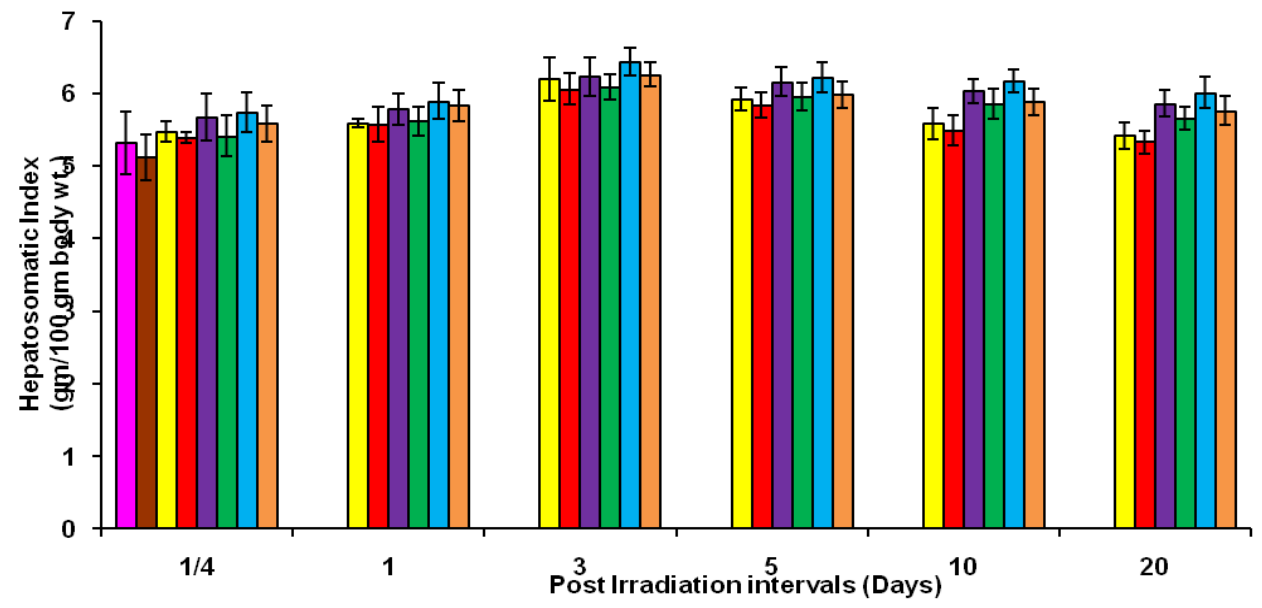

\begin{tabular}{|c|c|c|c|}
\hline ont. Set & $\begin{array}{l}\text { 口Aloe alone } \\
\text { व Gy Exptl. Set }\end{array}$ & $\begin{array}{l}\square 0.5 \text { Gy Cont. Set } \\
\square 5.5 \text { Gy Contl. Set }\end{array}$ & $\begin{array}{l}\square 0.5 \text { Gy Exptl. Set } \\
\square 5.5 \text { Gy Exptl. Set }\end{array}$ \\
\hline
\end{tabular}

Fig. 1: Hepatosomatic index (gm/100 gm body wt.) in swiss albino mice exposed to different doses of gamma radiation with and without pretreatment of Aloe

\section{DISCUSSION}

In the present investigation, hepatosomatic index (ratio of liver mass to body weight) increased and became higher in all control sets (irradiated alone) than normal mice. Secondly, we also recorded a dose-dependent increase in the hepatosomatic index from $6 \mathrm{~h}$ in both irradiated alone (control sets) and Aloe treated irradiated mice (experimental sets), which attained a peak at day 3. The hepatosomatic index decreased gradually thereafter and returned to almost normal level at day 20 in both 0.5 Gy irradiated alone and Aloe treated 0.5 Gy irradiated mice. However, in 3 and 5.5 Gy irradiated alone mice hepatosomatic index was 10 and 12 percent higher respectively than normal at day 20, while in Aloe treated 3 and 5.5 Gy irradiated mice the index was 6 and 8 percent higher respectively as mentioned in table 1 and fig. 1 .

Thus, an increase in the hepatosomatic index was lesser in Aloe treated irradiated mice in comparison to irradiated alone mice. These observations coincide with histopathological and biochemical observations where fatty degeneration was maximum between day 3 to 5 and glycogen and protein contents were the highest at day 5 in both irradiated alone and Aloe treated irradiated mice, which seem to be responsible for an increase in the hepatosomatic index in the present study. Earlier findings of several workers also support the 
results of this study. A significant increase was noticed in the liver mass in rats exposed to 2 Gy gamma radiations [6]. They stated that an increase in liver mass was attributed by the increase in water, lipid and glycogen contents in liver. Enlarged and increased number of cells and increased intercellular materials may also be one of the reasons for an increase in organ weight [7]. Lipid accumulation in liver after irradiation might be responsible for an increase in its weight [8]. Maximum hepatosomatic index at day 3 in 3 Gy and day 7 in $6 \mathrm{~Gy}$ (cumulative) exposed mice, which returned almost at normal level on day 14 and 18 respectively. He further stated that treatment with Liv. 52 before exposure prevented the increase in the hepatosomatic index and therefore, the increase was lesser in hepatosomatic index in Liv. 52 treated irradiated mice as compared to irradiated alone mice [9]. A significant increase in hepatosomaticindex in 5 Gy exposed mice was noticed from day 7 post-irradiation onwards. He further stated that an increase in the hepatosomatic index was lesser in Amaranthus and Spinacia extracts treated irradiated mice as compared to irradiated alone mice. He explained that increased fatty degeneration and oedema might have resulted in the increase of hepatosomatic index [10]. A significant increase in the value of hepatosomatic index in 6,8 and 10 Gy irradiated mice up to day 7, which decreased continuously thereafter till the last autopsy interval (day 30) without returning at a normal level. In her study, Rajgira leaf extract treated 6, 8 and 10 Gy irradiated mice showed lesser increase in the hepatosomatic index as compared to irradiated alone mice because of less fatty degeneration [11].

The study has been done with the changes in relative body wesight and liver weight of Mice exposed to different doses of Malathion, ranging from $0.1,0.5,0.10$ and $0.20 \mathrm{mg} / \mathrm{kg} / \mathrm{d}$ diet [12]. The result showed the body weight continued to increase up to $90 \mathrm{~d}$ of intoxication and liver weight increase up to $28 \mathrm{~d}$ of intoxication later on slightly decreased at $90 \mathrm{~d}$ of experimental periods. A study to examine the effect of ethanolic extract of Neem as an herb contraceptive to the hepato-somatic index of male mice has been done [13]. In this study hepatic weights and HSI values of control group (P0, Given distilled water) showed no significant differences ( $p>0.05$ ) compared to the P1 (Dose $8.4 \mathrm{mg} / \mathrm{KgBW} / \mathrm{d}$ ) and P2 (Dose $11.2 \mathrm{mg} / \mathrm{KgBW} / \mathrm{d})$ but showed significant differences $(\mathrm{P}<0.05)$ with P3 (Dose of $14 \mathrm{mg} / \mathrm{KgBW} / \mathrm{d}$ ) group.

\section{CONCLUSION}

The present study concluded that the administration of Aloe vera to mice helped in maintaining the balance up to some extend between antioxidant level, free radicals and therefore provided protection to mice liver.

Finally, it can be stated that oxidative stress can be minimized in human beings by the regular use of Aloe vera.

\section{ACKNOWLEDGMENT}

The author is thankful to the University of Rajasthan for providing research facilities and the Radiotherapy Department, SMS Medical College and Hospital, Jaipur, India for providing the irradiation facilities.

\section{AUTHORS CONTRIBUTIONS}

All the author have contributed equally

\section{CONFLICT OF INTERESTS}

Declare none

\section{REFERENCES}

1. Magnenat H, Gargano, Cao. The nature of antioxidant defense mechanisms: a lesson from transgenic studies. Oxygen/ Nitrogen Radicals Cellular 1998;106:1219-28.

2. Nair CK, Parida DK, Nomura T. Radioprotectors in radiotherapy. J Radiation Res 2001;42:21-37.

3. Copp RR, Peebles DD, Soref CM, Fahl WE. Radioprotective efficacy and toxicity of a new family of aminothiol analogs. Int J Radiation Biol 2013;89:485-92.

4. Pal S, Saha C, Dey SK. Studies on black tea (Camellia sinensis) extract as a potential antioxidant and a probable radioprotector. Radiat Environ Biophys 2013;52:269-78.

5. Atherton P. Aloe vera: magic or medicine? Nurs Stand 1998;12:49.

6. Suplee H, Weinman EO, Enteman C. Enlargement of the liver in sprague dewley rats following whole-body X-irradiation. Am J Physiol 1956;185:183.

7. Enesco M, Leblond CP. Increase in cell number as a factor in the organs and tissue of the young male rats. J Embryol Exptl Morphol 1962;10:530.

8. Iakovleva VI. Histological and histochemical study of the liver of the rats exposed on the cosmos-690 biosatellite. Kasm Biol Aviakosm Med 1978;12:24.

9. Purohit RK. Modification of radiation-induced changes in mammalian skin and liver by liv.52. Ph. D thesis, University of Rajasthan, Jaipur, India; 1996.

10. Jain M. Evaluation of antioxidative efficacy of certain plant extract: a study on mice liver. $\mathrm{Ph}$ D. thesis, University of Rajasthan, Jaipur, India; 2002.

11. Maharwal J. Radioprotective effect of certain plant extract on liver and intestine of swiss albino mice. Ph. D. thesis, University of Rajasthan, Jaipur, India; 2002.

12. Kaware MK. Changes in liver and body weight of mice exposed to the toxicant. Int Res J Sci Eng 2013;1:92-5.

13. Agung JS, Sri I, Siti MM. Effect of ethanolic neem (Azadirachta indica) leaf extract as an herb contraceptive on the hepato-somatic index of the male mice (Mus musculus). J Physics: Conf Series 2018;1025:1-6. 